\title{
Effects of standardized extract of Ferula gummosa root on glutamate-induced neurotoxicity
}

\author{
Hamid Reza Sadeghnia ${ }^{1,2,3}$, Arezoo Rajabian², Ahmad Ghorbani ${ }^{1}$, Maliheh Moradzadeh ${ }^{4}$, Azar Hosseini ${ }^{1}$ \\ ${ }^{1}$ Pharmacological Research Center of Medicinal Plants, Mashhad University of Medical Sciences, Mashhad, ${ }^{2}$ Department \\ of Pharmacology, Faculty of Medicine, Mashhad University of Medical Sciences, Mashhad, ${ }^{3}$ Division of Neurocognitive Sciences, \\ Psychiatry and Behavioral Sciences Research Center, Mashhad University of Medical Sciences, Mashhad, ${ }^{4}$ Golestan Rheumatology \\ Research Center, Golestan University of Medical Science, Gorgan, Iran
}

\begin{abstract}
Glutamate is one of the major excitatory neurotransmitters in the central nervous system. Increasing glutamate leads to neurodegenerative disease. Nowadays, plant medicine plays a role in the treatment of some disorders. In this research, we investigated the neuroprotective effect of Ferula gummosa root extract against glutamate-induced oxidative stress in the rat adrenal pheochromocytoma (PC12) and mouse neuroblastoma (N2a) cell lines. The cells were pretreated with extract for $2 \mathrm{~h}$ and then exposed to glutamate for $24 \mathrm{~h}$. After $24 \mathrm{~h}$ the level of malondialdehyde $(M D A)$, reactive oxygen species (ROS), and apoptotic cells were determined in both cell lines. Glutamate increased lipid peroxidation, ROS, and apoptotic cells in both cell lines. The extract significantly increased the cell viability and decreased the ROS generation under glutamate-induced oxidative stress in these cells. Also, the extract decreased the MDA level and apoptotic cells. The results showed that Ferula gummosa root may have a protective effect on glutamate-induced toxicity, suggesting that the extract protects neuronal cells from glutamate-induced oxidative stress.
\end{abstract}

Key words: PC12, N2a, glutamate, Ferula gummosa.

\section{Introduction}

Glutamate is released to synaptic spaces as a neurotransmitter in the central nervous system (CNS) and acts via binding to its receptor protein [3,5]. Increasing the glutamate concentration in the brain can lead to a number of neurodegenerative diseases such as stroke, epilepsy, depression, and Huntington's disease $[18,28]$. In vitro studies have shown that high concentrations of glutamate act as a potent neurotoxin that causes the death of neurons by apoptosis $[9,10]$. Different mechanisms can play role in glutamate toxicity in neuronal cells. Some of the mechanisms include activation of calcium-dependent enzymes [1], nitric oxide synthase [6], and the production of reactive oxygen species [39]. Recent studies have shown that antioxidant compounds, such as vitamin E [35], curcumin, and epicatechin gallate, protect primary cultured neurons from glutamate-induced cell death [41]. However, excessive accumulation of free radicals is responsible, at least in part, for glutamate-induced neuropathologies. Since plant medicinals contain different active ingredients, such as antioxidants, they

\section{Communicating author}

Dr. Azar Hosseini, Pharmacological Research Center of Medicinal Plants, Mashhad University of Medical Sciences, 9177948564 Mashhad, Iran, phone: 00985138002283, e-mail: hoseiniaz@mums.ac.ir 
may represent a viable approach by which glutamate toxicity can be reduced [32]. The present study was designed to evaluate the hypothesis that Ferula gummosa extract can protect neuronal cells against glutamate-induced toxicity. F. gummosa Boiss is from the Umbelliferae (Apiaceae) family. F. gummosa is known as barijeh in Persian. This plant grows in the northern and western parts of Iran. In traditional medicine, the roots of $F$. gummosa was used as a tonic, emmenagogue, anti-diarrhoea treatment, stomach pain medicine, epilepsy therapy, and as a wound healing remedy $[8,25]$. F. gummosa is composed of coumarin derivatives, such as umbelliprenin and terpenoids, and sesquiterpenes such as linalool, terpinolene, and valencene [30]. F. gummosa has different pharmacological effects including anticonvulsant [38], anti-nociceptive and anti-inflammatory [30], antioxidant [7], antimicrobial [37], and antiproliferative effects [19,11,14]. The presence of phenols and flavonoids in the extract can be responsible for the observed effects [7]. In this research, the neuroprotective effect of $F$. gummosa was evaluated on PC12 and N2a cell lines.

\section{Material and methods \\ Reagents and chemicals}

3-(4,5-dimethylthiazol-2-yl)-2,5-diphenyl tetrazolium (MTT), thiobarbituric acid (TBA), 2,7-dichlorofluorescin diacetate (DCFH-DA), propidium iodide (PI), sodium citrate, and Triton X-100 were purchased from Sigma (St. Louis, MO, USA). High-glucose Dulbecco's modified Eagle's medium (DMEM), penicillin-streptomycin, and foetal bovine serum were purchased from Gibco. Trichloroacetic acid (TCA) and malondialdehyde bis-(dimethyl acetal) (MDA) were obtained from Merck (Darmstadt, Germany). Rat pheochromocytoma (PC12, Pasteur Institute, C-1553, Tehran, Iran) and mouse neuroblastoma (N2a, ATCC, CCL-131PC12) cells were obtained from the Pasteur Institute (Tehran, Iran).

\section{Preparation of extract}

\section{Plant material and extraction}

The F. gummosa roots were collected from Alibolagh Valley (Khorasan Razavi Province, northeast Iran), and identified by Mohammadreza Joharchi, Ferdowsi University of Mashhad Herbarium (Voucher Specimen No. 4577). The hydroalcoholic extract was prepared using the Soxhlet method. The powder of
F. gummosa roots was subjected to extraction with $70 \%$ ethanol in a Soxhlet apparatus for $48 \mathrm{~h}$ [12], and the hydroalcoholic solvent was then evaporated by drying the extract in a water bath. The solid residue was stored at $-20^{\circ} \mathrm{C}$ until use.

\section{Standardizing the Ferula gummosa extract}

The hydroalcoholic extract of $F$. gummosa root was standardized by measuring the level of total phenol using the Folin-Ciocalteu reagent. A sample of F. gummosa extract $(20 \mu \mathrm{l}$ of $10 \mathrm{mg} / \mathrm{ml})$ or gallic acid standard solutions was mixed with $100 \mu \mathrm{l}$ Folin-Ciocalteu reagent and $300 \mu \mathrm{l}$ sodium carbonate solution ( $1 \mathrm{M})$, and the volume was adjusted to $2 \mathrm{ml}$ using deionised water. After two hours of incubation at room temperature, the absorbance was measured at $765 \mathrm{~nm}$ by spectrometer, and a standard curve was prepared for gallic acid. The total phenol level was expressed as milligrams of gallic acid equivalents per gram of dry F. gummosa extract.

\section{Cell culture and treatment}

The cells were maintained at $37^{\circ} \mathrm{C}$ in a humidified atmosphere that contained $5 \% \mathrm{CO}_{2}$. The cells were cultured in DMEM supplemented with $10 \%$ foetal bovine serum, 100 units/ml penicillin, and $100 \mu \mathrm{g} / \mathrm{ml}$ streptomycin. For the experiments, they were seeded in 96-well and 24-well culture plates for MTT/ROS and MDA assays, respectively. For apoptosis assay, cells were seeded at 100,000 cells/well in a 24-well plate. All treatments were carried out in triplicate. The cells were pretreated with extract alone $(25$ to $200 \mu \mathrm{g} / \mathrm{ml}$ ) for $2 \mathrm{~h}$, and then incubation was continued for $24 \mathrm{~h}$ in the presence of the extract with or without $8 \mathrm{mM}$ glutamate.

\section{Cell viability assay}

The MTT assay was applied for determination of cell viability [17]. The MTT powder was dissolved in phosphate-buffered saline $(5 \mathrm{mg} / \mathrm{ml})$ and added to each well at a final concentration of $0.05 \%$. After $3 \mathrm{~h}$, the formazan precipitate was dissolved in DMSO. The absorbance at 570 and $620 \mathrm{~nm}$ (background) was measured using a Stat FAX 303 plate reader.

\section{Lipid peroxidation assay}

The MDA was measured as lipid peroxidation index [17]. At the end of incubation, the cells were 
scraped and centrifuged for $30 \mathrm{~min}$. Then $400 \mu \mathrm{l}$ of TCA $(15 \%)$ and $800 \mu$ of TBA $(0.7 \%)$ were added to $500 \mu \mathrm{l}$ of cell samples. The mixture was vortexed and heated for $40 \mathrm{~min}$ in a boiling water bath. Then, 200 $\mu \mathrm{l}$ of the sample was transferred to a 96-well plate, and the fluorescence intensity was read with excitation/emission of $480 / 530 \mathrm{~nm}$. The experiment was carried out in triplicate.

\section{Measurement of reactive oxygen species}

The level of ROS was measured by DCFH-DA. At the end of the incubation, the cells were treated (30 min) with DCFH-DA $(10 \mu \mathrm{M})$ at $4^{\circ} \mathrm{C}$ in the dark. The fluorescence intensity was then detected with excitation/emission of $485 / 530 \mathrm{~nm}$. The experiment was performed in triplicate.

\section{Propidium iodide staining}

Propidium iodide (PI) staining was used for detection of apoptotic cells. It has previously been reported that a sub-G1 peak that is reflective of DNA fragmentation can be observed following the incubation of cells in a hypotonic phosphate-citrate buffer containing a quantitative DNA-binding dye such as PI. Apoptotic cells that have lost DNA will take up less stain and appear on the left side of the G1 peak in the histogram. Briefly, the cells were seeded in wells of a 24-well plate and treated according to the mentioned protocol. Floating and adherent cells were then harvested and incubated at $4^{\circ} \mathrm{C}$ overnight in the dark with $750 \mu \mathrm{l}$ of a hypotonic buffer $(50 \mu \mathrm{g} / \mathrm{ml} \mathrm{PI}$ in $0.1 \%$ sodium citrate with $0.1 \%$ Triton $\mathrm{X}-100)$. Next, flow cytometry was conducted using a FACScan flow cytometer (Becton Dickinson). A total of 104 events were acquired with FACS.

\section{Statistics}

All data were expressed as mean \pm SEM. Statistical analyses were performed using one-way analysis of variance (ANOVA) followed by Tamhane's T2 post-hoc test. Differences were considered significant at $p<0.05$.

\section{Results}

\section{Total phenol content of Ferula gummosa extract}

The solid residue of Soxhlet hydroalcoholic extract of F. gummosa was $19 \%$. Concentration of total phe- nol was $24 \mathrm{mg}$ gallic acid equivalent per gram of dry F. gummosa extract.

\section{Ferula gummosa significantly decreased the cell deaths induced by glutamate}

To study the possible toxic effects of extracts PC12 and N2a cells were incubated with different concentrations of extract $(6-200 \mu \mathrm{g} / \mathrm{ml})$, and the viability was determined $24 \mathrm{~h}$ after treatment. No significant toxic effect on cell viability was seen subsequent to treatment with extract. Incubation with glutamate significantly decreased cell viability to 51 $\pm 0.54 \%$ of control $(p<0.001)$. Results showed that treatment of PC12 cells with the extract increased cell viability at concentrations of $12-200 \mu \mathrm{g} / \mathrm{ml}$ $(12 \mu \mathrm{g} / \mathrm{ml}, 68 \pm 1.48 \%, p<0.05,25 \mu \mathrm{g} / \mathrm{ml}, 72 \pm$ $2.58 \%, p<0.01 ; 50 \mu \mathrm{g} / \mathrm{ml}, 78 \pm 2.8 \%, p<0.001$; $100 \mu \mathrm{g} / \mathrm{ml}, 82 \pm 4.38 \%, p<0.001 ; 200 \mu \mathrm{g} / \mathrm{ml}, 87 \pm$ $2.65 \%, p<0.001)$, while glutamate decreased cell viability to $50 \pm 2.6 \%, p<0.01$ (Fig. $1 \mathrm{~A}$ ). As shown in Figure $1 \mathrm{~B}$, treatment of $\mathrm{N} 2 \mathrm{a}$ cells with extract increased cell viability subsequent to glutamate insult at concentrations of $25-200 \mu \mathrm{g} / \mathrm{ml}$ dose dependently $(25 \mu \mathrm{g} / \mathrm{ml}, 65 \pm 2.1 \%, p<0.05 ; 50 \mu \mathrm{g} / \mathrm{ml}, 72 \pm 1.9 \%$, $p<0.001 ; 100 \mu \mathrm{g} / \mathrm{ml}, 80 \pm 2.2 \%, p<0.001 ; 200 \mu \mathrm{g} / \mathrm{ml}$, $86 \pm 2.5 \%, p<0.001)$.

\section{Ferula gummosa significantly decreased ROS content induced by glutamate}

As expected, glutamate caused a significant increase in the level of ROS in PC12 cells $(260 \pm 7.8 \%$ of control, $p<0.001)$. Extract at concentrations of $25-200 \mu \mathrm{g} / \mathrm{ml}$ was able to decrease intracellular ROS levels to $227 \pm 6.1 \%(p<0.05), 211 \pm 7.14 \%(p<0.01), 187$ $\pm 6.2 \%(p<0.001)$, and $172 \pm 5.7 \%(p<0.001)$ of control, respectively (Fig. 2A). Also, the extract decreased ROS levels in N2a cells at concentrations of $50 \mu \mathrm{g} / \mathrm{ml}$ $(168 \pm 4.5 \%, p<0.05), 100 \mu \mathrm{g} / \mathrm{ml}(151 \pm 9.1 \%, p<0.01)$, and $200 \mu \mathrm{g} / \mathrm{ml}(133 \pm 4.8 \%, p<0.001)$ against glutamate $(210.7 \pm 11 \%, p<0.001)$ (Fig. 2 B) .

\section{Ferula gummosa significantly decreased lipid peroxidation induced by glutamate}

The level of lipid peroxidation was evaluated by measuring the level of MDA, which is the end product of lipid peroxidation. As shown in Figure 3, expo- 

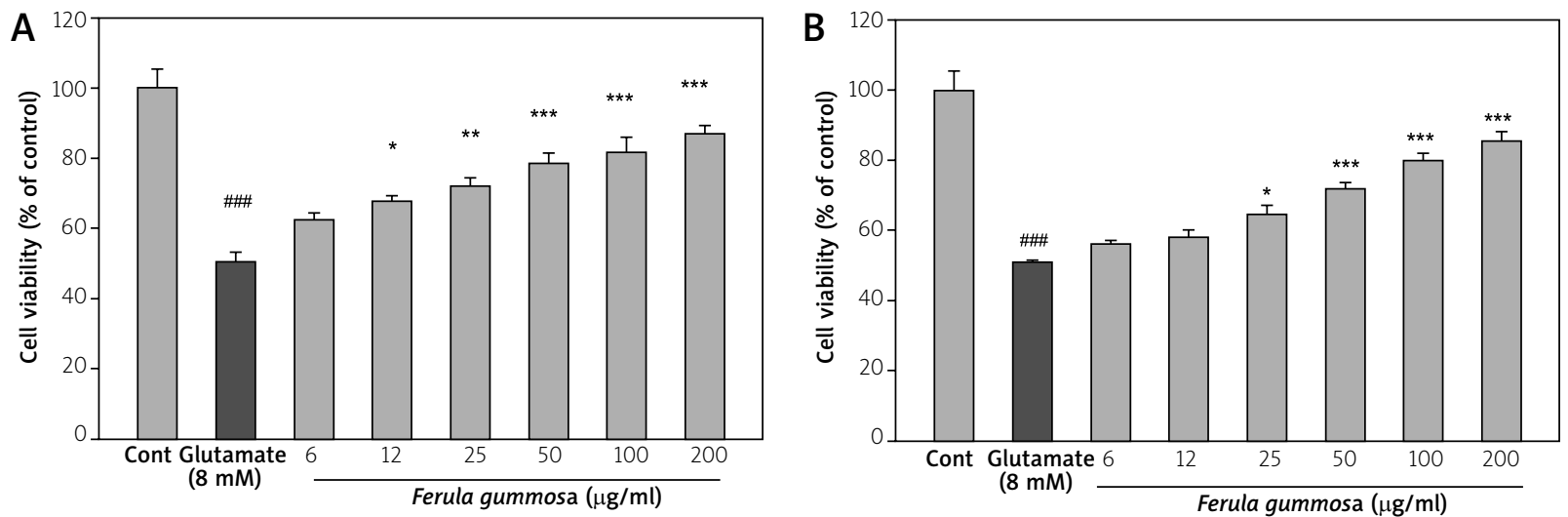

Fig. 1. Effect of Ferula gummosa on cell viability of glutamate-injured PC12 (A) and N2a (B) cells. The cells were pretreated with different concentrations of the extract for $2 \mathrm{~h}$ and then exposed to glutamate $(8 \mathrm{mM})$ for $24 \mathrm{~h}$. The cell viability was quantitated by MTT assay. Results are mean $\pm \operatorname{SEM}(n=3)$. \#\#\# $p<0.001$ versus control, ${ }^{*} p<0.05,{ }^{* *} p<0.01$ and ${ }^{* *} p<0.001$ versus glutamate.
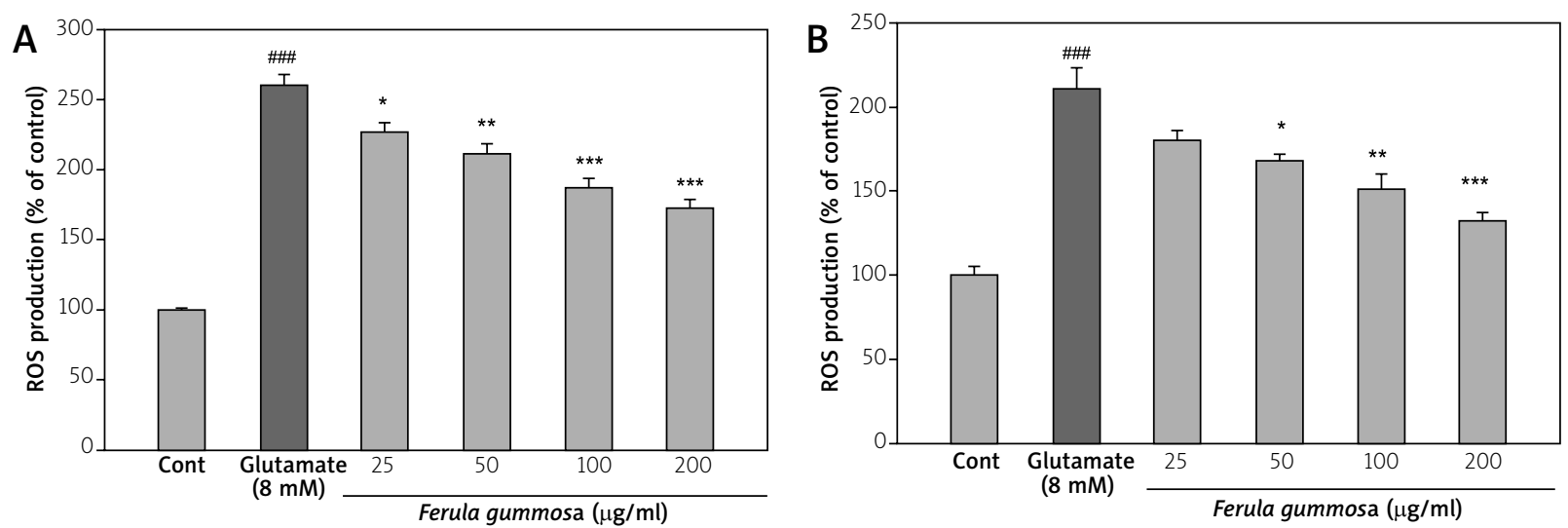

Fig. 2. Effect of Ferula gummosa on ROS generation in glutamate-injured PC12 (A) and N2a (B) cells. Results are mean $\pm \operatorname{SEM}(n=3) .{ }^{\# \# \# p} 0.001$ versus control, ${ }^{*} p<0.05,{ }^{* *} p<0.01$ and $^{* * *} p<0.001$ versus glutamate.
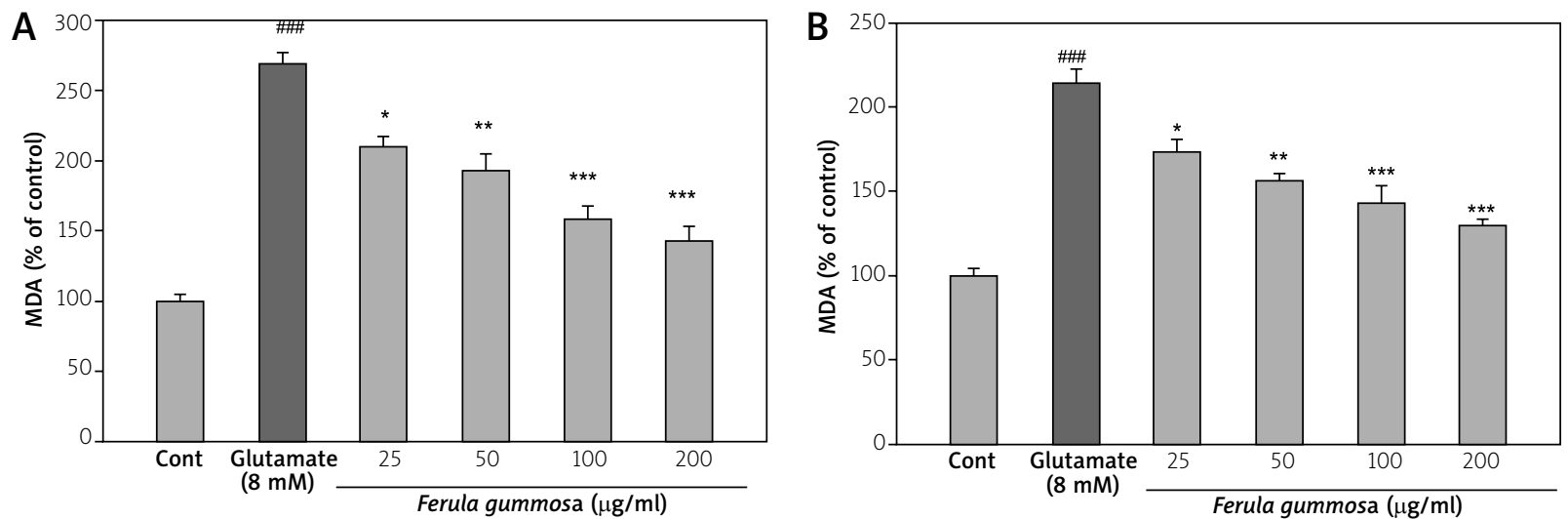

Fig. 3. Effect of Ferula gummosa on MDA production in glutamate-injured PC12 (A) and N2a (B) cells. The cells were pretreated with different concentrations of the extract for $2 \mathrm{~h}$ then exposed to glutamate $(8 \mathrm{mM})$ for $24 \mathrm{~h}$.

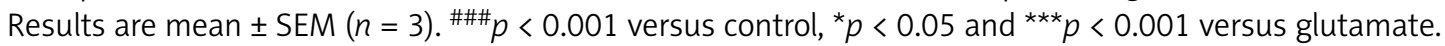


sure of the cells to glutamate resulted in a significant increase of MDA level in PC12 cells $(269 \pm 7.5 \%$, $p<0.001)$ as compared to control cells cultured in the absence of glutamate $(100 \pm 4.5 \%)$. The content of MDA was significantly decreased in the cells pretreated with $25 \mu \mathrm{g} / \mathrm{ml}(209 \pm 7.6 \%, p<0.05), 50 \mu \mathrm{g} /$ $\mathrm{ml}(193 \pm 11.6 \%, p<0.01), 100 \mu \mathrm{g} / \mathrm{ml}(158 \pm 9.7 \%$, $p<0.001)$, and $200 \mu \mathrm{g} / \mathrm{ml}(142 \pm 10.9 \%, p<0.001)$ of extract (Fig. 3A). The extract reduced the level of MDA at $25 \mu \mathrm{g} / \mathrm{ml}(173 \pm 7 \%, p<0.05), 50 \mu \mathrm{g} / \mathrm{ml}(156 \pm$
$4.5 \%, p<0.01), 100 \mu \mathrm{g} / \mathrm{ml}(143 \pm 10 \%, p<0.001)$, and $200 \mu \mathrm{g} / \mathrm{ml}(130 \pm 3.7 \%, p<0.001)$ against glutamate $(214 \pm 8.3 \%, p<0.001)$ (Fig. 3B).

\section{Ferula gummosa significantly decreased apoptotic cell death induced by glutamate}

Apoptosis in PC12 and N2a cell lines was detected with flow cytometry using PI staining. Cells were pretreated for $2 \mathrm{~h}$ with various concentrations of

A
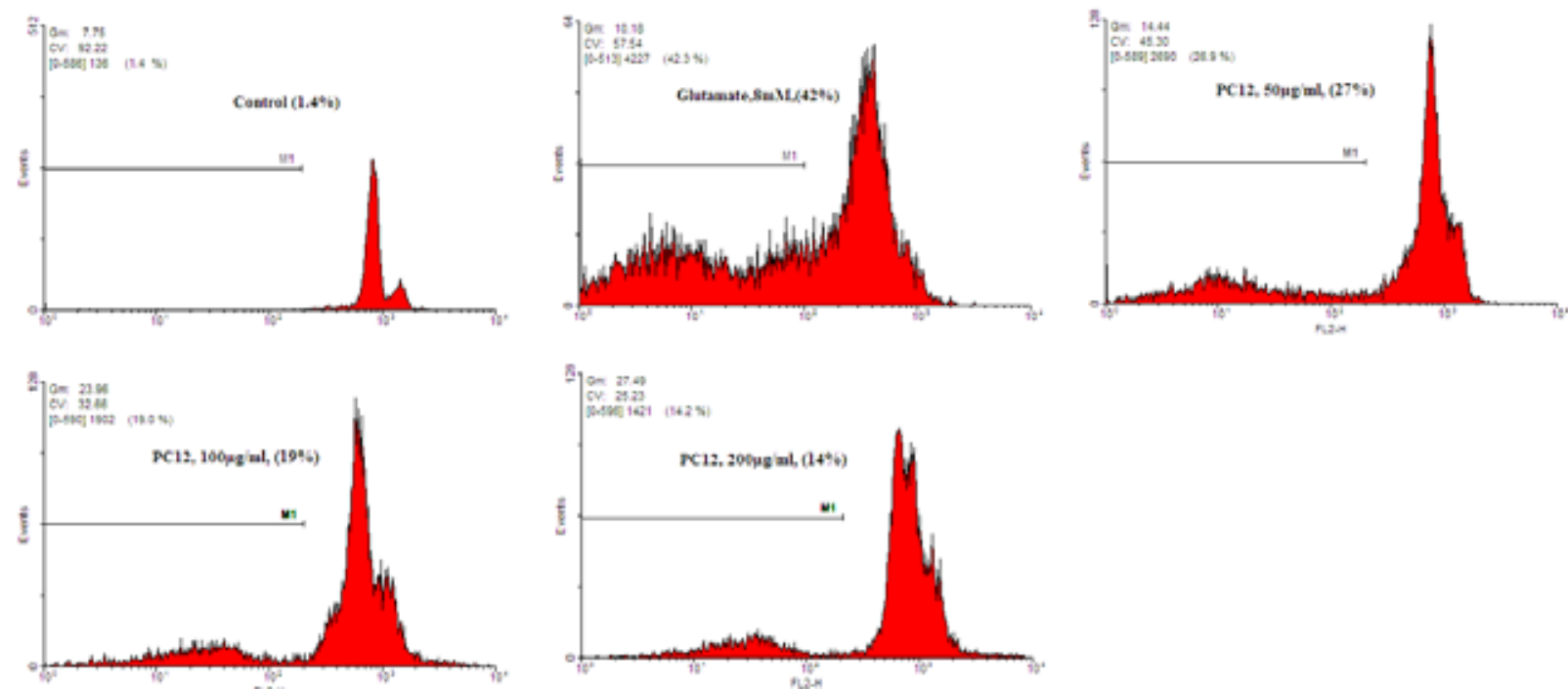

B
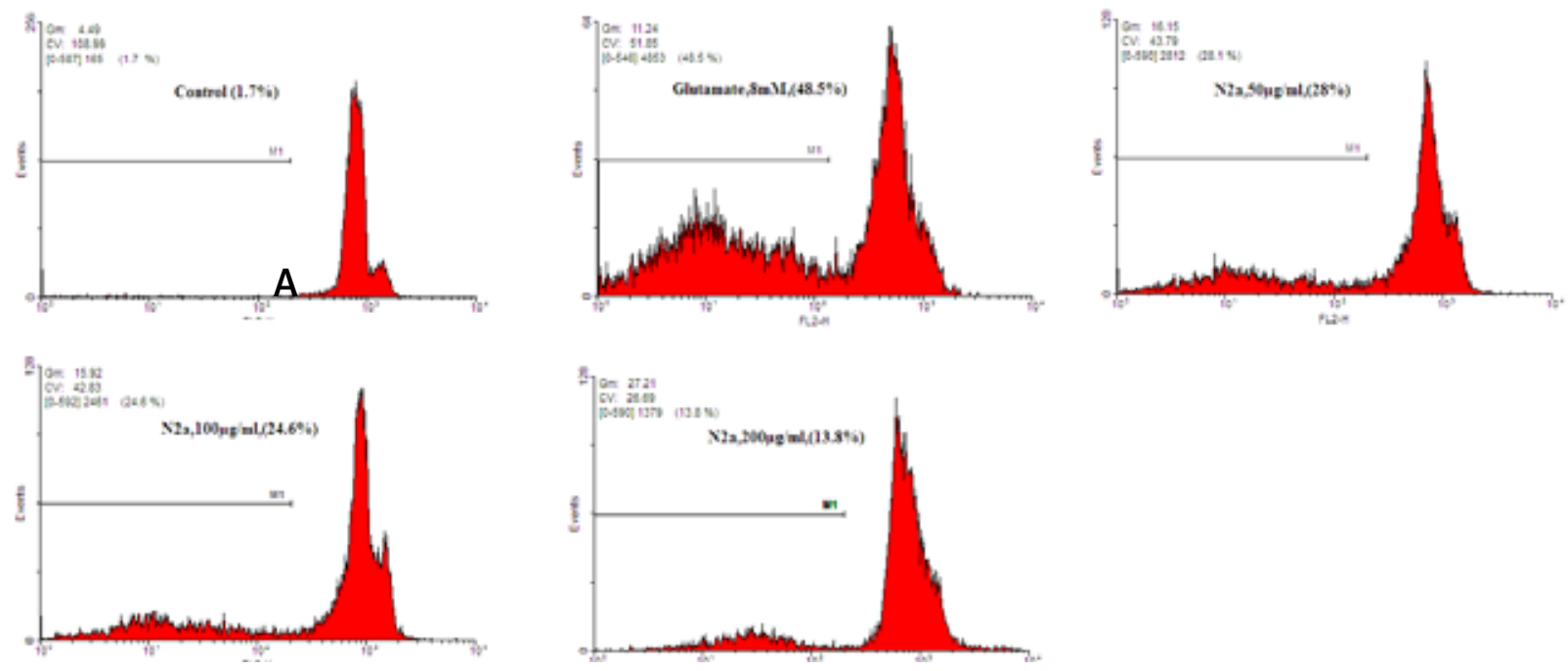

Fig. 4. The effects of extract of Ferula gummosa on apoptosis in PC12 (A) and N2a (B) cells using PI staining and flow cytometry. The cells were pretreated with different concentrations of the extract for $2 \mathrm{~h}$ then exposed to glutamate $(8 \mathrm{mM})$ for $24 \mathrm{~h}$. 
the F. gummosa and exposed to glutamate for $24 \mathrm{~h}$. Analysis of the sub G1 peak in flow cytometry histograms revealed the induction of apoptosis in cells treated with glutamate $(p<0.001)$.

\section{Discussion}

This study showed, for the first time, that F. gummosa has significant neuroprotective effects against glutamate-induced cytotoxicity in PC12 and $\mathrm{N} 2 \mathrm{a}$ cells in a dose-dependent manner. Whereas, dopamine and glutamate are synthesised in PC12 cell line [13]; however, this cell line can be appropriate for some studies, such as function of neurons, neuronal differentiation, and neurotoxicity [25]. PC12 cells are sensitive to glutamate toxicity; therefore, they can be used as a suitable model for investigating whether an extract has protective effect against glutamate-induced cytotoxicity. Increasing of glutamate can led to neuronal death in cerebral ischaemia [23] via glutamate receptor-mediated [21] and oxidative stress-mediated $[4,15]$. Recent studies have shown that glutamate exerts its toxic effects on PC12 in a dose- and time-dependent manner. Its toxic concentration varies between 0.01 and $10 \mathrm{mM}[29,34]$, while incubation time varies from $30 \mathrm{~min}$ to 3-12-24-48 h. The cytotoxicity effect of glutamate at very high doses [33] (5-10 mM) is independent of receptors and is mediated through the depletion of GSH and oxidative glutamate toxicity [25]. One way to reduce glutamate toxicity is to use antioxidant compounds such as medicinal plants. Recent studies have shown some herbal medicines have protective effects against glutamate such as peel and seed extract of Citrus aurantium [16], Persea major [8], Uncaria sinensis [20], Scrophularia striata Boiss [36], and Withania somnifera [22]. In this research, we used Ferula gummosa extract against glutamate toxicity in two cell lines: PC12 and N2a. The results revealed that the extract reduced ROS, lipid peroxidation, and apoptotic cells in treated cells in comparison with the glutamate group. There are different compounds in F. gummosa such as coumarin derivatives (umbelliprenin and terpenoids) and sesquiterpenes (linalool, terpinolene, and valencene) [30]. Polyphenols are found in vegetables, fruits, grains, bark, roots, and tea [26]. These compounds are important antioxidants [40] that have a neuroprotection effect against glutamate-induced excitotoxicity and ischaemia-induced neurodegeneration [27,31]. The studies have shown that linalool and eugenol, which are found in $F$. gummosa, have neuroprotective effects [2,24]. Eugenol is an agonist on $\gamma$-aminobutyric acid [23] (GABA) and an antagonist on NMDA (N-methyl-D-aspartate) glutamate receptors, which play an important role in pain transmission [2]. Also, linalool inhibits glutamate release in vitro and in vivo [24]. However, the results observed in this study may be related to the active compounds of F. gummosa; more studies are required to understand the accuracy mechanism in more detail.

\section{Disclosure}

Authors report no conflict of interest.

\section{References}

1. Ankarcrona M, Dypbukt JM, Orrenius S, Nicotera P. Calcineurin and mitochondrial function in glutamate-induced neuronal cell death. FEBS Lett 1996; 394: 321-324.

2. Anuj G, Sanjay S. Eugenol: a potential phytochemical with multifaceted therapeutic activities. Pharmacologyonline 2010; 2: 108120.

3. Bleich S, Römer K, Wiltfang J, Kornhuber J. Glutamate and the glutamate receptor system: a target for drug action. Int J Geriatr Psychiatry 2003; 18: S33-S40.

4. Chen J, Chua KW, Chua CC, Yu H, Pei A, Chua BH, Hamdy RC, XuX, Liu CF. Antioxidant activity of 7, 8-dihydroxyflavone provides neuroprotection against glutamate-induced toxicity. Neurosci Lett 2011; 499: 181-185.

5. Conn PJ. Physiological roles and therapeutic potential of metabotropic glutamate receptors. Ann N Y Acad Sci 2003; 1003: 12-21.

6. Dawson VL, Kizushi VM, Huang PL, Snyder SH, Dawson TM. Resistance to neurotoxicity in cortical cultures from neuronal nitric oxide synthase-deficient mice. J Neurosci 1996; 16: 2479-2487.

7. Ebrahimzadeh M, Nabavi S, Nabavi S, Dehpour A. Antioxidant activity of hydroalcholic extract of Ferula gummosa Boiss roots. Eur Rev Med Pharmacol Sci 2011; 15: 658-664.

8. Fedalto ML, Ludka FK, Tasca Cl, Molz S. Neuroprotection of Persea major extract against oxygen and glucose deprivation in hippocampal slices involves increased glutamate uptake and modulation of A1 and A2A adenosine receptors. Rev Bras Farmacogn 2013; 23: 789-795.

9. Froissard P, Duval D. Cytotoxic effects of glutamic acid on PC12 cells. Neurochem Int 1994; 24: 485-493.

10. Gerstner B, Lee J, DeSilva TM, Jensen FE, Volpe JJ, Rosenberg PA. $17 \beta$-estradiol protects against hypoxic/ischemic white matter damage in the neonatal rat brain. J Neurosci Res 2009; 87: 2078-2086.

11. Gharaei R, Akrami H, Heidari S, Asadi MH, Jalili A. The suppression effect of Ferula gummosa Boiss. extracts on cell proliferation through apoptosis induction in gastric cancer cell line. Eur J Integr Med 2013; 5: 241-247.

12. Ghorbani A, Rakhshandeh H, Sadeghnia H. Potentiating effects of Lactuca sativa on pentobarbital-induced sleep. Iran J Pharm Res 2013; 12: 401-406. 
13. Greene LA, Tischler AS. Establishment of a noradrenergic clonal line of rat adrenal pheochromocytoma cells which respond to nerve growth factor. Proceedings of the National Academy of Sciences 1976; 73: 2424-2428.

14. Gudarzi H, Salimi M, Irian S, Amanzadeh A, Mostafapour Kandelous H, Azadmanesh K, Salimi M. Ethanolic extract of Ferula gummosa is cytotoxic against cancer cells by inducing apoptosis and cell cycle arrest. Nat Prod Res 2015; 29: 546-550.

15. Hirata Y, Yamamoto H, Atta MSM, Mahmoud S, Oh-hashi K, Kiuchi K. Chloroquine inhibits glutamateinduced death of a neuronal cell line by reducing reactive oxygen species through sigma-1 receptor. J Neurochem 2011; 119: 839-847.

16. Hosseini A, Sadeghnia HR, Rajabian A. Protective effects of peel and seed extracts of Citrus aurantium on glutamate-induced cytotoxicity in PC12 cell line. Folia Neuropathol 2016; 54: 265-272.

17. Hosseini A, Shafiee-Nick R, Mousavi SH. Combination of Nigella sativa with Glycyrrhiza glabra and Zingiber officinale augments their protective effects on doxorubicin-induced toxicity in h9c2 cells. Iran J Basic Med Sci 2014; 17: 993.

18. Hu Y, Li J, Liu P, Chen X, Guo D-H, Li Q-S, Rahman K. Protection of SH-SY5Y neuronal cells from glutamate-induced apoptosis by 3,6'-disinapoyl sucrose, a bioactive compound isolated from Radix Polygala. J Biomed Biotechnol 2012; 2012: 1-5.

19. Iranshahi M, Masullo M, Asili A, Hamedzadeh A, Jahanbin B, Festa M, Capasso A, Piacente S. Sesquiterpene coumarins from Ferula gumosa. J Nat Prod 2010; 73: 1958-1962.

20. Jang JY, Kim HN, Kim YR, Hong JW, Choi YW, Choi YH, Shin HK, Choi BT. Hexane extract from Uncaria sinensis exhibits anti-apoptotic properties against glutamate-induced neurotoxicity in primary cultured cortical neurons. Int J Mol Med 2012; 30: 1465-1472.

21. Kanki R, Nakamizo T, Yamashita H, Kihara T, Sawada H, Uemura K, Kawamata J, Shibasaki H, Akaike A, Shimohama S. Effects of mitochondrial dysfunction on glutamate receptor-mediated neurotoxicity in cultured rat spinal motor neurons. Brain Res 2004; 1015: 73-81.

22. Kataria H, Wadhwa R, Kaul SC, Kaur G. Water extract from the leaves of Withania somnifera protect RA differentiated C6 and IMR-32 cells against glutamate-induced excitotoxicity. PLoS One 2012; 7: e37080.

23. Kim JY, Jeong HY, Lee HK, Kim S, Hwang BY, Bae K, Seong YH. Neuroprotection of the leaf and stem of Vitis amurensis and their active compounds against ischemic brain damage in rats and excitotoxicity in cultured neurons. Phytomedicine 2012; 19: 150-159.

24. Kim KY, Lee HS, Min SS, Seol GH. Neuroprotective Effect of (-)-Linalool against Sodium Nitroprusside-Induced Cytotoxicity. Med Chem 2015; 2015

25. Kritis AA, Stamoula EG, Paniskaki KA, Vavilis TD. Researching glutamate-induced cytotoxicity in different cell lines: a comparative/collective analysis/study. Front Cell Neurosci 2015; 9: 91.

26. Landete J. Updated knowledge about polyphenols: functions, bioavailability, metabolism, and health. Crit Rev Food Sci Nutr 2012; 52: 936-948.

27. Lee J, Son D, Lee P, Kim DK, Shin MC, Jang MH, Kim CJ, Kim YS, Kim SY, Kim H. Protective effect of methanol extract of Uncaria rhynchophylla against excitotoxicity induced by N-methyl-D-aspartate in rat hippocampus. J Pharmacol Sci 2003; 92: 70-73.
28. Lipton SA, Rosenberg PA. Excitatory amino acids as a final common pathway for neurologic disorders. N Engl J Med 1994; 330: 613-622.

29. Lu S, Lu C, Han Q, Li J, Du Z, Liao L, Zhao RC. Adipose-derived mesenchymal stem cells protect PC12 cells from glutamate excitotoxicity-induced apoptosis by upregulation of XIAP through PI3-K/Akt activation. Toxicology 2011; 279: 189-195.

30. Mandegary A, Sayyah M, Heidari MR. Antinociceptive and anti-inflammatory activity of the seed and root extracts of Ferula gummosa Boiss in mice and rats. Daru 2004; 12: 58-62.

31. Martini LH, Jung F, Soares FA, Rotta LN, Vendite DA, dos Santos Frizzo ME, Yunes RA, Calixto JB, Wofchuk S, Souza DO. Naturally occurring compounds affect glutamatergic neurotransmission in rat brain. Neurochem Res 2007; 32: 1950-1956.

32. Milutinović M, Stanković M, Cvetković D, Maksimović V, Šmit B, Pavlović R and Marković S. The Molecular Mechanisms of Apoptosis Induced by Allium flavum L. and Synergistic Effects with New-Synthesized Pd (II) Complex on Colon Cancer Cells. J Food Biochem 2015; 39: 238-250.

33. Murphy TH, Miyamoto M, Sastre A, Schnaar RL, Coyle JT. Glutamate toxicity in a neuronal cell line involves inhibition of cystine transport leading to oxidative stress. Neuron 1989; 2: 1547-1558.

34. Penugonda S, Mare S, Lutz P, Banks WA, Ercal N. Potentiation of lead-induced cell death in PC12 cells by glutamate: protection by $\mathrm{N}$-acetylcysteine amide (NACA), a novel thiol antioxidant. Toxicol Appl Pharmacol 2006; 216: 197-205.

35. Saito Y, Nishio K, Akazawa YO, Yamanaka K, Miyama A, Yoshida Y, Noguchi N, Niki E. Cytoprotective effects of vitamin $E$ homologues against glutamate-induced cell death in immature primary cortical neuron cultures: Tocopherols and tocotrienols exert similar effects by antioxidant function. Free Radic Biol Med 2010; 49: 1542-1549.

36. Salavati P, Ramezani M, Monsef-Esfahani HR, Hajiaghaei R, Parsa M, Tavajohi S, Ostad SN. Neuroprotective effect of total and sequential extract of Scrophularia striata Boiss. in rat cerebellar granule neurons following glutamate-induced neurotoxicity: an in-vitro study. Iran J Pharm Res 2013; 12: 389-394.

37. Salehi M, SM HK, Mobini M, Hedari A. Effect of aqueous and alcoholic extracts of roots of Ferula gummosa Boiss. on the growth of Pseudomonas aeruginosa. Journal of Gorgan University of Medical Sciences 2013; 15: 18-22.

38. Sayyah M, Mandegary A. Anticonvulsant effect of Ferula gummosa root extract against experimental seizures. Iran Biomed J 2003; 7: 139-143.

39. Urushitani M, Inoue R, Sawada H, Kihara T, Honda K, Akaike A, Shimohama S. N-methyl-D-aspartate receptor-mediated mitochondrial Ca2+ overload in acute excitotoxic motor neuron death: A mechanism distinct from chronic neurotoxicity after Ca2+ influx. J. Neurosci Res 2001; 63: 377-387.

40. Yang CS, Lambert JD, Sang S. Antioxidative and anti-carcinogenic activities of tea polyphenols. Arch Toxicol 2009; 83: 11-21.

41. Yazawa K, Kihara T, Shen H, Shimmyo Y, Niidome T, Sugimoto $H$. Distinct mechanisms underlie distinct polyphenol-induced neuroprotection. FEBS Lett 2006; 580: 6623-6628. 